\title{
Asymmetric distribution of histones during Drosophila male germline stem cell asymmetric divisions
}

\author{
Vuong Tran $\cdot$ Lijuan Feng $\cdot$ Xin Chen
}

(C) Springer Science+Business Media Dordrecht 2013

\begin{abstract}
It has long been known that epigenetic changes are inheritable. However, except for DNA methylation, little is known about the molecular mechanisms of epigenetic inheritance. Many types of stem cells undergo asymmetric cell divisions to generate self-renewed stem cells and daughter cells committed for differentiation. Still, whether and how stem cells retain their epigenetic memory remain questions to be elucidated. During the asymmetric division of Drosophila male germline stem cell (GSC), our recent studies revealed that the preexisting histone $3(\mathrm{H} 3)$ are selectively segregated to the GSC, whereas newly synthesized H3 deposited during DNA replication are enriched in the differentiating daughter cell. We propose a two-step model to explain this asymmetric histone distribution. First, prior to mitosis, preexisting histones and newly synthesized histones are differentially distributed at two sets of sister chromatids. Next, during mitosis, the set of sister chromatids that mainly
\end{abstract}

Responsible Editors: Helder Maiato and Yves Barral.

Vuong Tran and Lijuan Feng contributed equally to this work.

V. Tran $\cdot$ L. Feng $\cdot$ X. Chen

Department of Biology, The Johns Hopkins University,

Baltimore, MD 21218, USA

X. Chen $(\bowtie)$

Department of Biology, Johns Hopkins University,

3400 North Charles Street,

Baltimore, MD 21218-2685, USA

e-mail: xchen32@jhu.edu consist of preexisting histones are segregated to GSCs, while the other set of sister chromatids enriched with newly synthesized histones are partitioned to the daughter cell committed for differentiation. In this review, we apply current knowledge about epigenetic inheritance and asymmetric cell division to inform our discussion of potential molecular mechanisms and the cellular basis underlying this asymmetric histone distribution pattern. We will also discuss whether this phenomenon contributes to the maintenance of stem cell identity and resetting chromatin structure in the other daughter cell for differentiation.

Keywords Germline stem cell $\cdot$ epigenetics $\cdot$ transcription $\cdot$ canonical histones $\cdot$ histone variant $\cdot$ Drosophila testis $\cdot$ spermatogenesis

$\begin{array}{ll}\text { Abbreviations } \\ \text { GSC } & \text { Germline stem cell } \\ \text { GB } & \text { Gonialblast } \\ \text { H3 } & \text { histone } 3 \\ \text { ACD } & \text { Asymmetric cell division } \\ \text { Upd } & \text { Unpaired } \\ \text { PCNA } & \text { Proliferating cell nuclear antigen } \\ \text { HDAC } & \text { Histone deacetylases } \\ \text { PcG } & \text { Polycomb group } \\ \text { TrxG } & \text { Trithorax group } \\ \text { BrdU } & \text { Bromodeoxyuridine } \\ \text { SSIS } & \text { Strand-specific imprinting and selective } \\ & \text { chromatid segregation }\end{array}$


$\begin{array}{ll}\text { CO-FISH } & \begin{array}{l}\text { Chromosome orientation-fluorescence in } \\ \text { situ hybridization }\end{array} \\ \text { Cnn } & \text { Centrosomin }\end{array}$

\section{Asymmetric cell divisions of adult stem cells}

Stem cells are unique in their ability to both self-renew and give rise to a variety of differentiated cell types. Adult stem cells are naturally existing cell populations that maintain tissues, such as blood, intestine, muscle, skin, and the gonads. Many of them undergo asymmetric cell division to generate a self-renewed stem cell and a daughter cell which will subsequently enter differentiation (Betschinger and Knoblich 2004; Clevers 2005; Morrison and Kimble 2006; Inaba and Yamashita 2012). Normal activities of adult stem cells are required for homeostasis, tissue regeneration, and fertility. The misdetermination of stem cell fate or the malfunction of stem cell derivatives are common causes of human diseases, such as diabetes, muscular dystrophy, neurodegenerative disease, infertility, and many forms of cancer (Feinberg et al. 2006; Morrison and Kimble 2006; Rando 2006; Rossi et al. 2008). It is of particular interest to understand the molecular circuitries underlying the unique features of adult stem cells.

The Drosophila male and female germline stem cells (GSCs) are among the best characterized adult stem cell systems in terms of their physiological locations, microenvironments or niches, cellular structures, and the signaling pathways that maintain their stem cell identities (Fuller and Spradling 2007; Morrison and Spradling 2008; Losick et al. 2011). Like many other types of adult stem cells [see (Morrison and Kimble 2006; Knoblich 2008; Inaba and Yamashita 2012) for reviews on asymmetric cell division], GSCs undergo asymmetric cell division (ACD) to balance self-renewal and differentiation for tissue homeostasis. Taking male GSC as an example, the ACD outcome is ensured by both extrinsic cues in the niche and intrinsic factors in the GSC (Yamashita and Fuller 2005; Yamashita et al. 2005; Fuller and Spradling 2007). One critical extrinsic cue for male GSC is the Unpaired (Upd) ligand for the JAK-STAT signaling pathway. Upd emanates from a group of post-mitotic cells at the tip of fly testis, constituting a "hub" structure (Kiger et al. 2001; Tulina and Matunis 2001; Toledano et al. 2012). Activated JAK-STAT signaling is required for maintaining GSCs, which are attached to hub cells by adherens junctions (Kiger et al. 2001; Tulina and Matunis 2001; Yamashita et al. 2003; Leatherman and Dinardo 2008; Inaba et al. 2010; Leatherman and Dinardo 2010). In addition to extrinsic signals, intrinsic factors inside male GSCs also contribute to the proper ACD of GSCs. For example, male GSCs always retain the mother centrosome that is anchored at the GSC-hub interface, while the newly synthesized daughter centrosome migrates to the opposite end of GSC. This asymmetric segregation of centrosomes serves as an important intrinsic mechanism to set up proper spindle orientation for ACD of GSCs (Yamashita et al. 2003; Yamashita et al. 2007). Interestingly, in GSC where centrosomes are misoriented, mitotic spindle does not form, therefore, GSC is arrested and cannot proceed with mitosis. This phenomenon has promoted the "centrosome orientation checkpoint" hypothesis as an intrinsic mechanism to ensure ACD (Cheng et al. 2008; Inaba et al. 2010; Roth et al. 2012; Yuan et al. 2012a).

\section{Epigenetic inheritance to maintain cell identity}

In eukaryotic nuclei, DNA is organized into nucleosomes by wrapping around histone octamers $[2 \times(\mathrm{H} 3$, $\mathrm{H} 4, \mathrm{H} 2 \mathrm{~A}, \mathrm{H} 2 \mathrm{~B})]$, which act as fundamental units to form the higher-order chromatin structure. Epigenetic mechanisms that alter chromatin structure, while preserving primary DNA sequences, contribute significantly to "cellular memory," which maintains a particular cell fate through many cell divisions (Jacobs and van Lohuizen 2002; Turner 2002; Ringrose and Paro 2004). Epigenetic regulation can occur at the level of DNA itself, such as DNA methylation, or at DNA-associated proteins, such as histones. The extensive post-translational modifications of histones have profound impacts on regulating gene expression (Jenuwein and Allis 2001; Schreiber and Bernstein 2002; Turner 2002; Fischle et al. 2003; Berger 2007). Adult stem cells may have a chromatin structure distinct from differentiated cells for their unique molecular characteristics, such as gene expression pattern (Jenuwein and Allis 2001; Jaenisch and Young 2008; Eun et al. 2010) and alternative splicing pattern (Chepelev and Chen 2013).

Among all epigenetic mechanisms, DNA methylation is the best understood one responsible for 
epigenetic inheritance based on its semi-conservative manner of propagation (Martin and Zhang 2007; Bonasio et al. 2010). It has also been shown that certain histone modifications at constitutively active genes, such as hyperacetylation of $\mathrm{H} 3$ and $\mathrm{H} 4$ or $\mathrm{H} 3 \mathrm{~K} 4 \mathrm{me} 2 / 3$ and $\mathrm{H} 3 \mathrm{~K} 79 \mathrm{me} 2$, are maintained in mitotic cells when global transcription is shut off, suggesting that histone modifications could serve as molecular memory bookmarks to recapitulate the transcription activation domain after mitosis (Kouskouti and Talianidis 2005; Valls et al. 2005). In addition to active histone modifications, repressive histone modifications, such as $\mathrm{H} 3 \mathrm{~K} 9 \mathrm{me} 3$, also remain associated with chromatin during mitosis (Fischle et al. 2005) and is probably responsible for faithful inheritance of heterochromatin structure (Motamedi et al. 2004; Irvine et al. 2006). However, it is unclear whether and how histone modification patterns could be inherited in stem cells and/or reestablished in their differentiating daughter cells during ACD.

Replication-coupled canonical histone deposition

The bulk of canonical histones are synthesized and incorporated during DNA replication when the entire genome duplicates. During this process, it is commonly accepted that $\mathrm{H} 3$ and $\mathrm{H} 4$ are incorporated as a tetramer, while $\mathrm{H} 2 \mathrm{~A}$ and $\mathrm{H} 2 \mathrm{~B}$ are incorporated as dimers (Jackson and Chalkley 1981a, b; Russev and Hancock 1981; Annunziato et al. 1982; Xu et al. 2010). Replication-dependent histone deposition is a highly regulated process and requires an orchestrated series of events, including disruption and recycling of preexisting octamers, as well as deposition of newly synthesized histones at the replication fork (Corpet and Almouzni 2009). Abnormal nucleosome assembly and deposition could cause failure in genome stability and increased sensitivity to DNA damage, which may lead to tumorigenesis and other diseases. This process must be coordinated very efficiently to assemble chromatin right after the passage of replication fork (Gasser et al. 1996; Guilbaud et al. 2011; Smith and Whitehouse 2012).

Incorporation of newly synthesized histones is facilitated by chromatin remodeling complexes (Saha et al. 2006), histone chaperones (De Koning et al. 2007), and histone-modifying enzymes (Corpet and Almouzni 2009). Chromatin remodelers have ATPase activity, which can slide nucleosome and facilitate disruption of preexisting nucleosome in preparation for replication-coupled reformation. Newly synthesized histones first undergo specific modifications at their $\mathrm{N}$ termini; for example, lysine 56 of $\mathrm{H} 3$ and lysine 5 and 12 of $\mathrm{H} 4$ are acetylated (Ai and Parthun 2004; Masumoto et al. 2005). The acetylation marks of $\mathrm{H} 3$ and $\mathrm{H} 4$ allow their binding to histone chaperones CAF-1, ASF-1, and Rtt106 to facilitate H3-H4 assembly and deposition (Verreault et al. 1996; Recht et al. 2006; Chen et al. 2008; Li et al. 2008). Histone chaperones coordinate deposition of newly assembled histones through direct interaction with proliferating cell nuclear antigen (PCNA), a processivity factor for DNA polymerase, at the replication fork (Shibahara and Stillman 1999; Moggs et al. 2000). After deposition, the acetylated histone modifications are removed by HDAC (Ruiz-Carrillo et al. 1975; Jackson et al. 1976).

In addition to acetylation, histone lysine methylations may also play important roles during epigenetic inheritance. For example, increasing evidence indicates that "cellular memory" of Homeobox gene expression is maintained by a balance between the repressive $\mathrm{H} 3 \mathrm{~K} 27 \mathrm{me} 3$ and active $\mathrm{H} 3 \mathrm{~K} 4 \mathrm{me} 3$ marks generated by the polycomb group ( $\mathrm{PcG}$ ) and the trithorax group (TrxG) complexes, respectively (Ringrose and Paro 2004; Hansen and Helin 2009; Zhu and Reinberg 2011). Interestingly, PcG remains at the DNA replication forks in vitro (Francis 2009a, b; Francis et al. 2009). Interactions between two different PcG complexes through dimerization can prevent their dissociation from chromatin during DNA replication (Lengsfeld et al. 2012; Lo et al. 2012). A recent in vivo study examined histone methylation marks in S phase cells from Drosophila embryos (Petruk et al. 2012). Consistent with the in vitro work, this study shows that both PcG and TrxG proteins bind to newly synthesized DNA at their response elements and associate with PCNA. However, neither $\mathrm{H} 3 \mathrm{~K} 4 \mathrm{me} 3$ nor H3K27me3 was detected at replication forks in S phase cells. Instead, unmodified H3 was found to be in close proximity to PCNA and newly synthesized DNA. These data suggest that histonemodifying enzymes reestablish histone methylation patterns after the passage of replication fork.

Despite increased knowledge on incorporation of newly synthesized histones during DNA replication, our understanding about whether and how preexisting histones are recycled at replication forks is limited. 
Transmission of histone modification information from mother cell to two daughter cells is critical for reliable inheritance. On the other hand, resetting this information may be important when the two daughter cells must distinguish from each other during ACD of adult stem cells or different fate choices during lineage specification.

\section{Replication-independent histone variant deposition}

Increasing evidence indicates that histone variants influence epigenetic inheritance via a transcriptioncoupled mechanism (Henikoff et al. 2004a, b). However, in contrast to canonical histones, deposition of the histone variants is replication-independent. One of the best characterized histone turnovers during transcription is the replacement of canonical $\mathrm{H} 3$ with the H3.3 variant (Ahmad and Henikoff 2002b; Schwartz and Ahmad 2005). This replacement is more frequent at gene regulatory regions such as TrxG and $\mathrm{PcG}$ response elements, actively transcribed coding sequences, and replication origins (Mito et al. 2007; Deal et al. 2010). This process requires histone chaperones, such as HirA (Ray-Gallet et al. 2002), Daxx, and Atrx (Drane et al. 2010; Goldberg et al. 2010), as well as chromatin remodeling complexes (Konev et al. 2007). H3.3 can potentially transmit either active or repressive chromatin state to maintain the epigenetic memory of gene expression during mitosis or meiosis (Szenker et al. 2011).

In addition to $\mathrm{H} 3.3$, other histone variants play distinct roles in a variety of different cellular processes (Kamakaka and Biggins 2005). Among them, CENP$\mathrm{A}$ is an $\mathrm{H} 3$ variant found specifically at the centromere region, which is also deposited in a replicationindependent manner (Ahmad and Henikoff 2002a). CENP-A may play a critical role in differentially labeling the two sister chromatids for asymmetric epigenetic inheritance, which will be discussed later.

\section{Two models to explain the unique molecular properties of stem cells}

The "immortal strand" hypothesis

To explain how stem cells maintain their unique genome and epigenome characteristics through successive cell divisions, the immortal strand hypothesis was postulated more than three decades ago. It holds that stem cells retain "immortal" DNA strands to minimize the incidence of mutations, which may arise during pathological progression or aging and, in turn, lead to stem cell abnormalities and dysfunctions (Cairns 1975).

Evidence to support or oppose this hypothesis has accumulated [discussed in (Lansdorp 2007; Rando 2007) and other reviews in this issue]. In some systems, stem cells retain the parental DNA strands (Merok et al. 2002; Potten et al. 2002; Karpowicz et al. 2005; Smith 2005; Armakolas and Klar 2006; Shinin et al. 2006; Conboy et al. 2007; Karpowicz et al. 2009; Pine et al. 2010; Quyn et al. 2010; Rocheteau et al. 2012), whereas in others, DNA strands segregate randomly (Kiel et al. 2007; Sotiropoulou et al. 2008; Waghmare et al. 2008; Fei and Huttner 2009; Yadlapalli et al. 2011a). The apparent conflict may partially result from the fact that these experiments were performed in different cell types from distinct organisms, and some of them were not performed with adult stem cells in vivo. To test the "immortal strand" hypothesis, most studies have used pulse-chase with nucleotide analogs, e.g., bromodeoxyuridine (BrdU), to label older or newer strands. Thus, if parental DNA strands are labeled and become immortal, stem cells would have long BrdU retention. Alternatively, if the newer strands are labeled, they will not be retained in stem cells but specifically displaced to the differentiating cells. However, stem cells are not always identifiable at single-cell resolution. In addition, if the timing to label stem cells is not precise, it is possible that progenitor cells and even differentiated cells are labeled instead. Therefore, it is critical to have reliable markers to locate stem cells versus differentiating cells precisely.

The "silent sister chromatid" or "strand-specific imprinting and selective chromatid segregation" (SSIS) model

Another explanation of the epigenetic inheritance of stem cells is the "silent sister chromatids" hypothesis (Lansdorp 2007), which holds that sister chromatids carry different epigenetic marks at the centromeric region or at specific genomic loci in stem or progenitor cells. Conceivably there are two different epigenetic marks based on their distinct locations and functions: Nonequivalent centromeric epigenetic marks are 
required for nonrandom chromatid segregation, while different epigenetic marks at gene-enriched genomic loci regulate differential gene expression. In contrast to self-renewing cells, which selectively inherit chromatids with active expression of "stemness" genes, differentiated daughter cells inherit the chromatids silent for "stemness" genes. Similar to the "silent sister chromatids" hypothesis, the strand-specific imprinting and selective chromatid segregation (SSIS) model also proposes that epigenetically distinct sister chromatids cosegregate (Klar 1994, 2007).

Evidence supporting these two similar models came from experiments that can distinguish sister chromatids. For example, in one study, a genetic manipulation was introduced specifically to mouse chromosome 7 , which showed biased sister chromatid segregation pattern in a cell type-specific manner (Armakolas and Klar 2006). Recently, a CO-FISH (chromosome orientationfluorescence in situ hybridization) method was used to distinguish sister chromatids using unidirectional probes specific for centromeric or telomeric repeats and test for silent sister chromatid hypothesis (Falconer et al. 2010). Using this method, it was shown that in a subpopulation of adult skeletal stem cells, all sister chromatids segregate asymmetrically with a bias for the parental DNA strand containing ones retained in the stem cells (Rocheteau et al. 2012). More recent work in Drosophila male GSC demonstrated that sex chromosomes (X and Y chromosomes), but not autosomes, have biased sister chromatid segregation (Yadlapalli and Yamashita 2013).

In all these models discussed above, both centromeres and centrosomes are hypothesized to be asymmetric to achieve the asymmetric segregation pattern (Lansdorp 2007; Lew et al. 2008; Tajbakhsh and Gonzalez 2009). Asymmetric centromeres may be established through leading versus lagging strand difference if replication of the centromeric region is biased toward a unidirectional movement of the replication fork, which has been shown in Escherichia coli (White et al. 2008). However, no evidence has shown unidirectional movement of replication fork in eukaryotic cells. Alternatively, asymmetric centromeres may be at the epigenetic level by their unique chromatin structure (Vagnarelli et al. 2008; Malik and Henikoff 2009; Verdaasdonk and Bloom 2011). Asymmetric centrosome segregation has been reported in Drosophila male GSCs (Yamashita et al. 2007), neuroblasts (Rebollo et al. 2007), and mouse neural progenitor cells (Wang et al. 2009). To test if asymmetric inheritance of centrosome may be utilized for biased segregation of DNA strands, BrdU was used to label newly synthesized DNA strands in asymmetrically dividing male GSCs; however, the results exhibit random segregation (Yadlapalli et al. 2011a). Interestingly, in the same system, mutations in a centrosome component $\mathrm{Cnn}$ resulted in randomized centrosome segregation (Yamashita et al. 2007), as well as randomized sex chromosome segregation (Yadlapalli and Yamashita 2013). However, it remains unclear whether randomized centrosome is the causal reason for the loss of asymmetric sex chromosome segregation. Therefore, the connection between asymmetric centrosome segregation and biased DNA strand or sister chromatid inheritance will await future studies [(Tajbakhsh and Gonzalez 2009) and (Yamashita 2013)].

\section{Asymmetric epigenetic inheritance in Drosophila male germline stem cells}

Because stem cells and differentiated cells share the same genome, stem cells' unique molecular characteristics are defined by a distinct gene expression pattern and their ability to maintain this pattern over time. It is attractive to hypothesize that epigenetic mechanisms play an important role in determining stem cell fate and that epigenetic inheritance is critical for stem cell maintenance. However, most studies of epigenetic inheritance have been performed in vitro using biochemical tools [reviewed in (McNairn and Gilbert 2003; Martin and Zhang 2007)], and none was from an in vivo stem cell system.

We decided to study epigenetic inheritance in Drosophila male GSCs, based on several advantages of this system. (1) DNA methyl-transferase activity is almost negligible in adult flies (Hung et al. 1999; Lyko et al. 2000a, b; Richards and Elgin 2002). Histones are likely major carriers of epigenetic information. Therefore, we focused our studies on histone inheritance, which simplifies the experimental design. (2) Drosophila GSCs can be identified by their distinct anatomical positions and morphological features within the fly testis. This makes it feasible to visualize these stem cells under their physiological conditions. (3) Male GSCs undergo consistent ACDs, and, remarkably, the two daughter cells from ACD of GSCs can be readily identified, enabling a direct comparison. 
(4) The length of each stage of GSC cell cycle has been well characterized (Yamashita et al. 2003, 2007; Cheng et al. 2008; Sheng and Matunis 2011; Yadlapalli et al. 2011a), allowing precise mapping of temporal changes in the context of cell cycle. (5) In addition to temporal changes, the existing Gal4/UAS system allows a great spatial resolution when using transgenes.

Based on existing knowledge and reagents, we developed a dual-color histone labeling system, similar to a previously reported strategy (Verzijlbergen et al. 2010). Using this system, preexisting histones can be precisely distinguished from newly synthesized histones because an irreversible DNA recombination induced the old-to-new histone switch (Tran et al. 2012). After the genetic switch in G2 phase GSCs (75\% among all GSCs), we allowed them to undergo one round of cell cycle because genome-wide incorporation of newly synthesized $\mathrm{H} 3$ occurs in $\mathrm{S}$ phase. We then traced the distribution of old versus new $\mathrm{H} 3$ in the GSC-GB (gonialblast) pair derived from the second mitosis of GSC after genetic switch. Strikingly, preexisting H3 was found to be asymmetrically distributed in GSCs, while newly synthesized H3 were enriched in GBs. Noticeably, when GSC and GB are connected by a cellular structure called spectrosome due to incomplete cytokinesis, both cells are undergoing the second S phase after genetic switch (Sheng and Matunis 2011; Yadlapalli et al. 2011a). Because of the dynamic turnover of old $\mathrm{H} 3$ and incorporation of new $\mathrm{H} 3$ during $\mathrm{S}$ phase, the ratio of $\mathrm{H} 3$ in GSC versus GB has a wide range of distribution, which is more variable for old $\mathrm{H} 3$ (GFP ratio in GSC/GB) than for new $\mathrm{H} 3$ (mKO ratio in GB/GSC) (Fig. 1a). This could be due to the more dynamic turnover of old $\mathrm{H} 3$ in GB or the limitation of sensitivity since quantification of fluorescence in fixed samples is not real-time and semi-quantitative.

As a control, we looked at the symmetrically dividing progenitor cells and found no evidence of asymmetric histone distribution (Fig. 1b). We further screened for GSCs undergoing the second mitosis after genetic switch, in particular those at anaphase or telophase. We were very surprised to find that old and new $\mathrm{H} 3$ are asymmetrically segregated during ACD, suggesting that the asymmetric distribution of H3 in GSC-GB pair does not totally result from post-mitotic histone turnover.

As discussed earlier, JAK-STAT signaling is critical for GSC maintenance, and ectopic JAK-STAT activity leads to ectopic GSC self-renewal outside the niche environment (Kiger et al. 2001; Tulina and Matunis
2001; Leatherman and Dinardo 2008, 2010). We found that the asymmetric $\mathrm{H} 3$ distribution pattern was lost in testis where ectopic JAK-STAT leads to symmetric GSC division. This result suggests that the asymmetric $\mathrm{H} 3$ distribution pattern relies on the different fates between the two daughter cells derived from ACD. However, because changing JAK-STAT activity affects many cellular and molecular features in GSCs, it is still difficult to distinguish whether the symmetric $\mathrm{H} 3$ distribution is a causal reason or consequential event for the loss of ACD.

Using the same labeling strategy, we also studied the histone variant H3.3. In contrast to H3, H3.3 does not exhibit this asymmetric pattern during GSC divisions (Fig. 1b). H3 is mostly deposited during $\mathrm{S}$ phase, whereas H3.3 can be incorporated at any stage during cell cycle. The symmetric distribution pattern of H3.3 leads us to hypothesize that DNA replication may play a role in establishing this asymmetry. We also hypothesize that this asymmetric distribution of $\mathrm{H} 3$ may maintain the unique molecular properties of male GSCs. However, after a prolonged time after genetic switch (i.e., 3 days after heat shock), the preexisting $\mathrm{H} 3$ became undetectable in GSCs (Tran, V. unpublished), suggesting that there is no "immortal histone." We therefore hypothesize that chromatin factors, such as histone-modifying enzymes, could modify newly synthesized H3 using information from preexisting $\mathrm{H} 3$, after which preexisting $\mathrm{H} 3$ could be dispensable during the next cell cycle. More studies are needed to dissect the molecular mechanisms and cellular basis that underlie this asymmetric $\mathrm{H} 3$ distribution during ACD of male GSCs. We will discuss potential mechanisms in the later part of this review.

Another interesting phenomenon is a potential faster turnover of preexisting $\mathrm{H} 3$ in the GB cells. We found symmetric segregation patterns of both old and new $\mathrm{H} 3$ in GSCs undergoing the first mitosis after genetic switch. The first mitosis is before $\mathrm{S}$ phase; therefore, new H3 signal is very weak since replicationindependent $\mathrm{H} 3$ replacement is not at the genomewide level (Dion et al. 2007). However, in the postmitotic GSC-GB pair undergoing S phase, we observed much weaker old $\mathrm{H} 3$ signal in the GB compared with GSC (Fig. 1c). This differential distribution of $\mathrm{H} 3$ in post-mitotic GSC-GB is specific because it was not observed in symmetrically dividing progenitor cells with $\mathrm{H} 3$ transgene or in the GSC-GB pair with $\mathrm{H} 3.3$ transgene [Fig. 1d and (Tran et al. 2012)]. We 

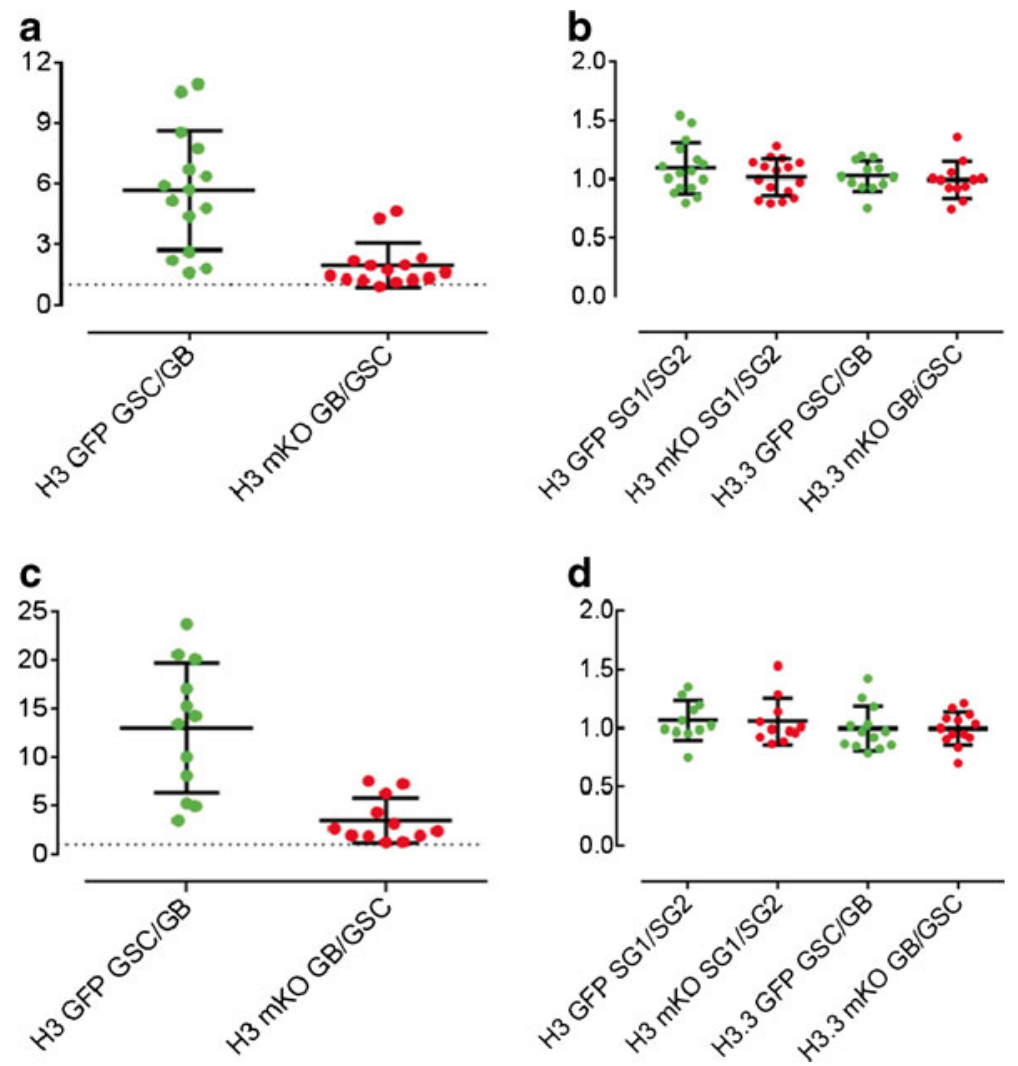

Fig. 1 GFP and mKO fluorescence intensity ratio from (Tran et al. 2012) re-plotted using scatter dot to show the dynamic range of $\mathrm{H} 3$ in $\mathrm{S}$ phase GSC-GB pairs. Detailed mean $\pm \mathrm{SD}$ is as follows. a For the second $\mathrm{S}$ phase, $\mathrm{H} 3 \mathrm{GSC} / \mathrm{GB}$ GFP ratio $-5.66 \pm 2.94\left[\mathrm{H} 3 \mathrm{GSC} / \mathrm{GB}\right.$ GFP ratio $\left.>1 \quad\left(\mathrm{P}<10^{-4}\right)\right], \mathrm{H} 3$ $\mathrm{GB} / \mathrm{GSC} \mathrm{mKO}$ ratio-1.94 $\pm 1.10(\mathrm{~N}=15) \quad[\mathrm{GB} / \mathrm{GSC} \mathrm{mKO}$ ratio $\left.>1\left(\mathrm{P}<10^{-4}\right)\right]$. b $\mathrm{H} 3$ two-cell spermatogonial (SG) SG1/ $\mathrm{SG} 2$ GFP ratio- $1.09 \pm 0.22, \mathrm{SG} 1 / \mathrm{SG} 2 \mathrm{mKO}$ ratio $-1.02 \pm 0.15$ $(N=16)$ [neither ratio is significantly different from $1, P>0.1$ ]. H3.3 GSC/GB GFP ratio- $1.03 \pm 0.13, \mathrm{H} 3.3 \mathrm{~GB} / \mathrm{GSC} \mathrm{mKO}$

hypothesize that faster histone turnover in GB could erase the epigenetic memory and prime GB for differentiation. This could be another unique feature for adult stem cell ACD because one of the two daughter cells will need to initiate a robust transcription program for terminal differentiation (Lim et al. 2012).

\section{Potential mechanisms contributing to asymmetric histone distribution}

The finding of differential segregation of preexisting versus newly synthesized H3 during ACD of GSCs suggests coordinated molecular and cellular events in GSCs. First, prior to mitosis, preexisting H3 and

ratio $-0.99 \pm 0.16(N=12)$ [neither ratio is significantly different from $1, P>0.1]$. $\mathbf{c}$ For the first $\mathrm{S}$ phase, $\mathrm{H} 3 \mathrm{GSC} / \mathrm{GB}$ GFP ratio$13.00 \pm 6.75\left[\mathrm{H} 3 \mathrm{GSC} / \mathrm{GB}\right.$ GFP ratio $\left.>1\left(P<10^{-4}\right)\right], \mathrm{H} 3 \mathrm{~GB} / \mathrm{GSC}$ $\mathrm{mKO}$ ratio $-3.46 \pm 2.30 \quad(N=12) \quad[\mathrm{GB} / \mathrm{GSC} \mathrm{mKO}$ ratio $>1$ $\left.\left(P<10^{-4}\right)\right]$. d H3 two-cell spermatogonial (SG) SG1/SG2 GFP ratio $-1.07 \pm 0.17, \mathrm{SG} 1 / \mathrm{SG} 2 \mathrm{mKO}$ ratio- $1.06 \pm 0.19(N=$ 11) [neither ratio is significantly different from $1, P>0.1$ ]. H3.3 GSC/GB GFP ratio- $1.00 \pm 0.19, \mathrm{H} 3.3 \mathrm{~GB} / \mathrm{GSC} \mathrm{mKO}$ ratio$1.00 \pm 0.14(N=13)$ [neither ratio is significantly different from 1 , $P>0.1]$. The dotted lines in a and $\mathbf{c}$ denote 1:1 ratio

newly synthesized H3 have already differentially distributed to the two sets of sister chromatids. Second, during mitosis, the mitotic machinery can distinguish the set of sister chromatids carrying preexisting $\mathrm{H} 3$ from the other set enriched with newly synthesized $\mathrm{H} 3$, followed by partitioning them to GSCs and GBs, respectively. Here, we will discuss several models to explain this intriguing observation.

Replication-dependent differential H3 deposition onto sister chromatids in S phase GSCs

As discussed earlier, DNA replication is a highly regulated process which requires a high degree of cooperation among DNA synthesis, histone synthesis, and 
incorporation. Because parental H3-H4 tetramer does not dissociate during replication (Seale 1975) and H3 and $\mathrm{H} 4$ carry the majority of the known histone modifications (Bannister and Kouzarides 2011), it is possible that $\mathrm{H} 3$ and $\mathrm{H} 4$ are responsible for transmitting most of the epigenetic information. On the other hand, H2A$\mathrm{H} 2 \mathrm{~B}$ dimer readily dissociates from the octamer at replication forks; therefore, they may not be the major players.

However, since eukaryotic cells have multiple replication forks during S-phase, the next question is how all replication forks coordinate the deposition of old versus new $\mathrm{H} 3$ onto two sister chromatids, respectively. Because a replication fork is bi-directional, histone loading cannot depend on the difference between leading and lagging strands. It has been reported recently that the two sister chromatids of either $\mathrm{X}$ or $\mathrm{Y}$ chromosome are segregated asymmetrically during GSC division (Yadlapalli et al. 2011b; Yadlapalli and Yamashita 2013). However, this asymmetry of sister chromatid segregation does not apply to autosomes (Yadlapalli and Yamashita 2013), suggesting that the preferential partitioning of old H3 into GSCs is not completely dependent on DNA strand difference.

We hypothesize that it is epigenetic difference that distinguishes the two sister chromatids during the first $\mathrm{S}$ phase after genetic switch (Fig. 2a), which could be different histone modifications. For example, the H3K27me3 mark generated by PcG could be recognized by the chromodomain of polycomb protein. Because polycomb group proteins can dimerize (Min et al. 2003; Lengsfeld et al. 2012; Lo et al. 2012) and directly interact with PCNA at the replication fork (Petruk et al. 2012), it is possible that, through dimerization, polycomb coordinates preferential retention of preexisting $\mathrm{H} 3-\mathrm{H} 4$ tetramers carrying the H3K27me3 mark onto one sister chromatid at the replication fork (Fig. 2b). Epigenetic marks on preexisting histones may contribute to maintain unique gene expression pattern in stem cells. Although H3K27me3 was not detected at replication forks in Drosophila embryos, it is possible that this phenomenon is different in stem cells because embryonic cells have a fast cell cycle and undergo symmetric cell divisions.

Replication-independent differential H3 turnover at sister chromatids in G2 phase GSCs

Another model that may contribute to this asymmetric histone distribution pattern relies on replicationindependent histone turnover. In this model, old and new H3 are incorporated randomly onto sister chromatids during $\mathrm{S}$ phase. However, during the subsequent elongated G2 phase (Fig. 3a), new histones replace old a

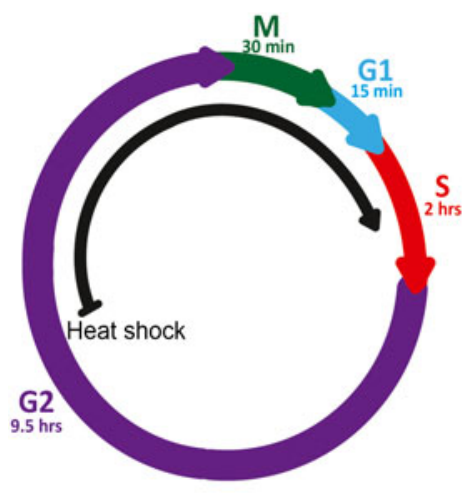

b

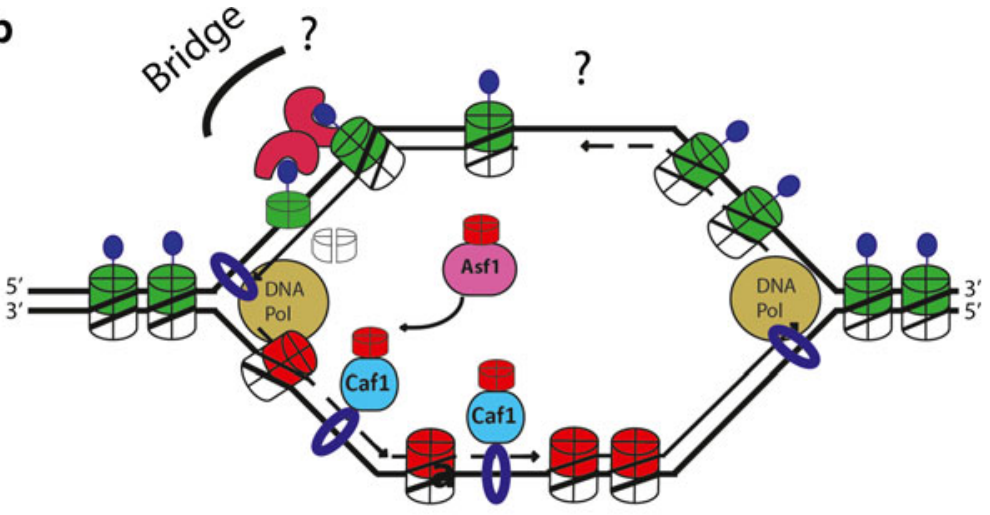

$\mathrm{H} 2 \mathrm{~A}-\mathrm{H} 2 \mathrm{~B}$ dimers

preexisting $\mathrm{H} 3-\mathrm{H} 4$ tetramer

new $\mathrm{H} 3-\mathrm{H} 4$ tetramer
Fig. 2 Replication-dependent histone deposition model. a Cell cycle information: The first $\mathrm{S}$ phase after genetic switch is discussed here. b H3-H4 tetramers are retained and loaded in a chromatid-specific manner at the replication fork. PcG binds specifically to old histone $\mathrm{H} 3$ that carries the H3K27me3 mark. PcG-PcG dimerization could bridge two $\mathrm{H} 3-\mathrm{H} 4$ tetramers to ensure their incorporation into the same sister chromatid. For simplicity, only one H3K27me3-Pc-Pc- H3K27me3 is shown here 

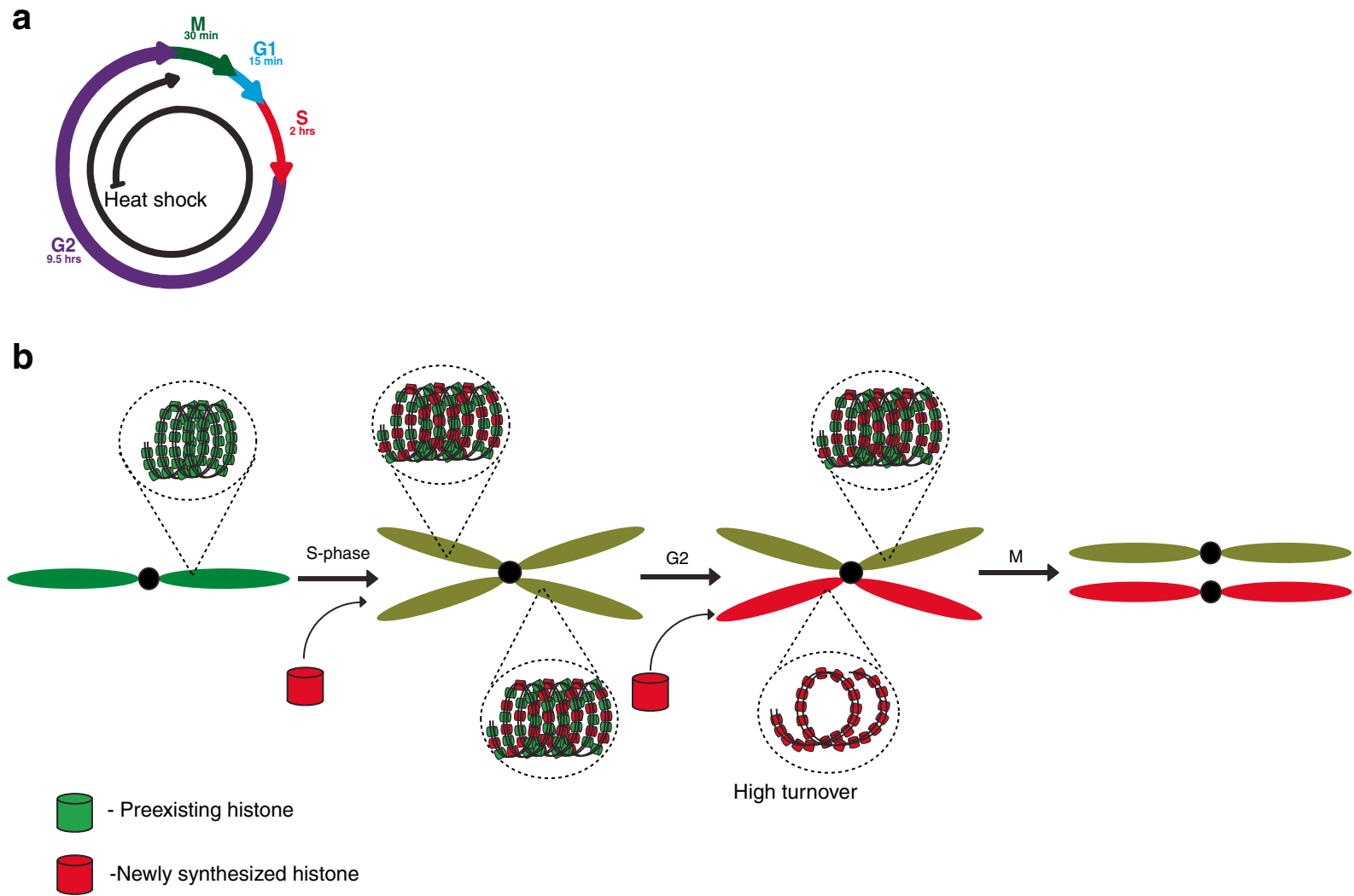

Fig. 3 Replication-independent histone turnover model. a Cell cycle information: The second G2 phase after genetic switch is discussed here. b Asymmetry between sister chromatids could be established in G2 phase, when one sister has a higher

ones in a sister chromatid-specific manner (Fig. 3b). As discussed previously, nucleosomes undergo dynamic turnover at actively transcribed regions or regulatory elements, and either histone variants such as H3.3 (Mito et al. 2007; Deal et al. 2010) or newly synthesized H3 (Dion et al. 2007) could replace preexisting H3. In this context, it is possible that sister chromatids have different chromatin states, leading to higher transcriptional activity and faster histone turnover of one sister chromatid compared with another one. This difference could then result in differential distribution of old versus new histones toward the end of G2 phase. This active replacement mechanism is especially appealing since the Drosophila male GSC spend most time in G2 phase [9-10 h out of a 12-h cycle (Yamashita et al. 2003, 2007; Cheng et al. 2008; Sheng and Matunis 2011; Yadlapalli et al. 2011a)]. The prolonged G2 may give the chromatin remodeler sufficient time to establish sister chromatid asymmetry through regulation of histone turnover. We observed a higher ratio of preexisting H3 in GSC turnover of old $\mathrm{H} 3$ and allows more incorporation of newly synthesized H3. For simplicity, only one pair of sister chromatids are shown here

compared with GB in the first cell cycle compared with the second one [Fig. 1a and c, (Tran et al. 2012)], suggesting that random incorporation of preexisting histones onto the two sister chromatids during S phase, followed by sister chromatid-specific turnover in G2 phase, could be involved.

Asymmetric chromatin states between homologous chromosomes have been shown for $\mathrm{X}$ inactivation, which requires long noncoding RNAs, such as Xist, to silence one $\mathrm{X}$ chromosome in female mammalian cells (Borsani et al. 1991). Although it is unclear how different chromatin states between two sister chromatids are determined, one possible mechanism is through noncoding RNAs (Bernstein and Allis 2005; Tajbakhsh and Gonzalez 2009; Bonasio et al. 2010; Rinn and Chang 2012). For example, one sister chromatid could transcribe a Xist-like non-coding RNA, which could then recruit PcG to generate the H3K27me3 mark to spread the silencing effect (Zhao et al. 2008). Subsequently, different transcriptional activity between two sister chromatids could be 
established, and the sister chromatid without PcGmediated repression would be more transcriptionally active, resulting in a higher rate of histone turnover. In addition to long non-coding RNAs, RNAi machinery that normally produces small non-coding RNAs has also been shown to establish heterochromatin in fission yeast, suggesting an intimate interplay between noncoding RNAs and chromatin structure (Bayne et al. 2010). Another example of different chromatin states between homologous chromosomes comes from studies of allelic exclusion, which result in one active allele and one silent allele. This could happen at the transcriptional level such as imprinting due to differential DNA methylation (Ferguson-Smith 2011) or at the post-transcriptional level which results in removal of protein product of one allele (Mostoslavsky et al. 2004).

The differential S-phase deposition model and G2-phase turnover model are not mutually exclusive. It is also possible that the asymmetry between two sister chromatids is established at some, but not all, genomic regions during $\mathrm{S}$ phase. For example, it was hypothesized that different nucleosomal density exists at particular gene loci due to asymmetric distribution of PCNA and histone chaperones between leading and lagging strands (Shibahara and Stillman 1999). Different nucleosomal density can lead to differential gene expression (Nakano et al. 2011) or directly affect histone-modifying enzymes, such as PcG activity (Yuan et al. 2012b). Such an asymmetry could be subsequently expanded to the major, if not entire, chromosomal region during G2 phase, which would lead to a genome-wide epigenetic difference between two sets of sister chromatids prior to mitosis. Future studies to determine the timing and to identify such epigenetic differences between sister chromatids will undoubtedly shed light on the cellular and molecular mechanisms underlying asymmetric histone inheritance during ACD of Drosophila male GSCs.

Mitotic machinery asymmetrically segregates sister chromatids in M phase GSCs

If preexisting $\mathrm{H} 3$ and newly synthesized $\mathrm{H} 3$ are differentially distributed at two sets of sister chromatids prior to mitosis, the next question is how they are recognized by the mitotic machinery in GSC (Fig. 4a). According to the silent sister chromatid hypothesis, different epigenetic marks at centromeric region of the sister chromatids could establish their attachment to a polarized mitotic spindle.
In Drosophila S2 cells, CENP-A homolog called CID is recruited to centromeric region at metaphase (Mellone et al. 2011), which is interspersed with nucleosomes containing canonical H3 (Blower et al. 2002). In Drosophila embryos, CENP-A is found to be incorporated into centromeres at anaphase (Schuh et al. 2007). However, the timing of CENP-A incorporation in male GSCs is unknown. If it happens at metaphase in a sister chromatid-specific manner, it may contribute to the asymmetric segregation of $\mathrm{H} 3$ in male GSCs (Fig. 4b). In addition to CENP-A, centromeric chromatin has a unique histone modification pattern, which may be responsible for their specific functions during mitosis (Sullivan and Karpen 2004; Vagnarelli et al. 2008). For example, the $\mathrm{H} 3 \mathrm{~K} 4 \mathrm{me} 2$ mark at centromeric region is required for kinetochore assembly at centromeres (Sullivan and Karpen 2004; Bergmann et al. 2011). Kinetochore is the protein structure on chromatids whereby the spindle fibers attach to pull sister chromatids apart. Kinetochore facilitates interaction between centromeric chromatin and dynamic microtubules. Components of the yeast kinetochore were reported to divide asymmetrically (Thorpe et al. 2009). However, it is unclear whether asymmetric kinetochores also exist in higher eukaryotes. Interestingly, kinetochoreassociated kinesin-7 was reported to regulate sequential congression of chromosomes to the equator in mammalian cells, which may allow temporal difference for mitotic spindle to anchor different sister chromatids (Kapoor et al. 2006). In Drosophila male GSCs, the mother centrosome was reported to have higher microtubule-organizing center activity (Yamashita et al. 2007). It is possible that microtubules emanating from the mother centrosome anchor preexisting $\mathrm{H} 3$-enriched sister chromatids, possibly through regulation by asymmetric kinetochore, CENP-A, or other epigenetic marks at the centromeric region (Fig. 4b). Remarkably, a recent study in male GSCs revealed that sister chromatids from homologous autosomes co-segregate even though there is no strand preference (Yadlapalli and Yamashita 2013). If the asymmetry between preexisting and newly synthesized H3 on sister chromatids has already been established prior to mitosis (Figs. 2 and 3), co-segregation of sister chromatids from homologous autosomes ( $\sim 80 \%$ of genome) could greatly facilitate the asymmetric segregation of $\mathrm{H} 3$ during mitosis (Fig. 4c). Motor proteins like Dynein may also contribute to asymmetric chromatid segregation (Armakolas and Klar 2007). 


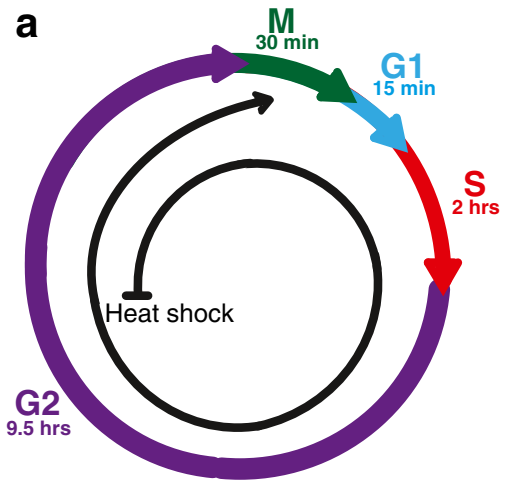

b

Metaphase

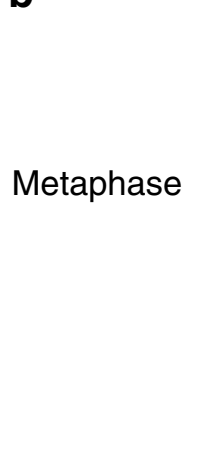

C

Anaphase
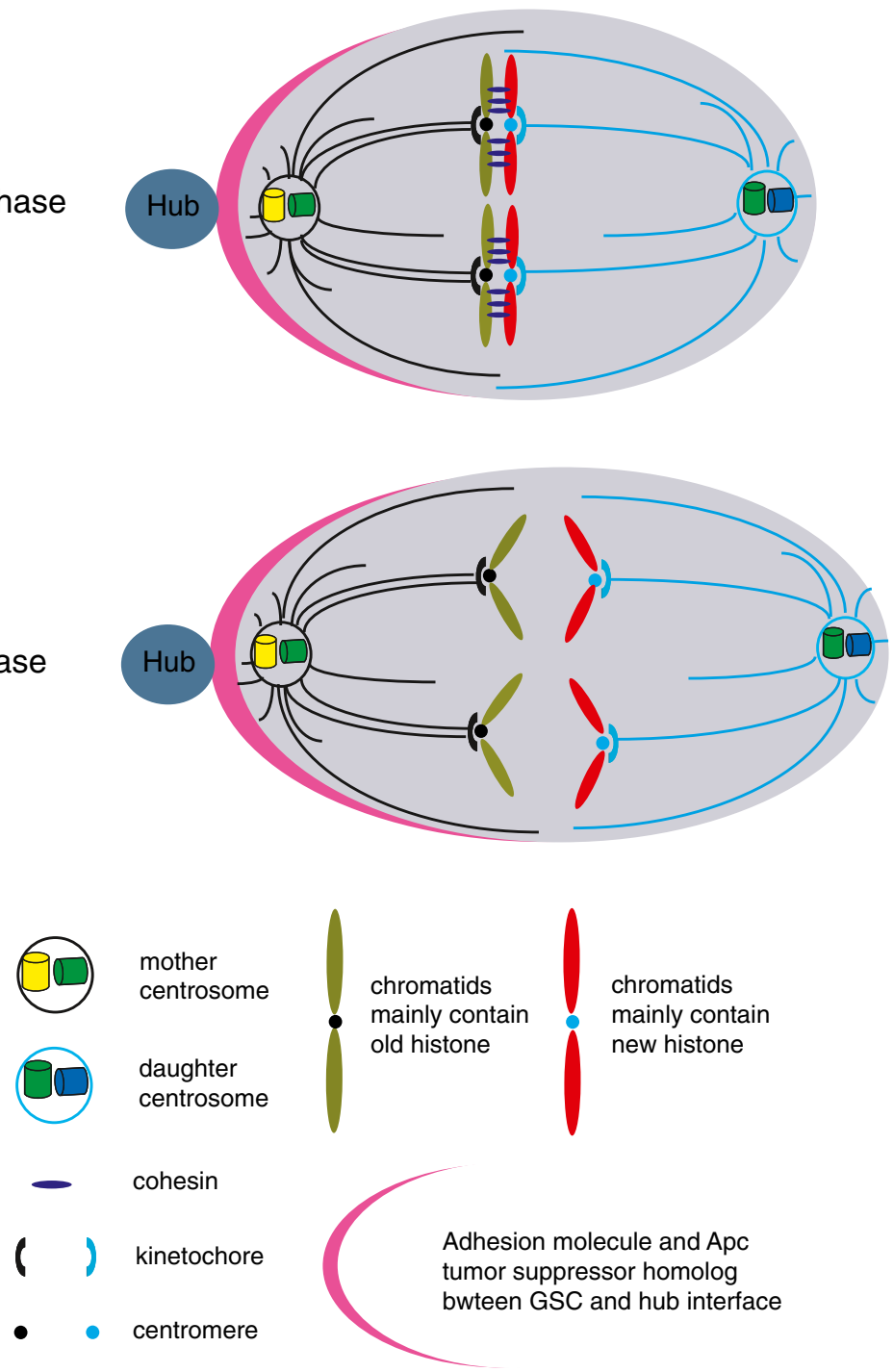

Fig. 4 Asymmetric segregation of sister chromatids carrying different sets of histones. a Cell cycle information: The second $\mathrm{M}$ phase after genetic switch is discussed here. b At metaphase, microtubules from mother centrosome attach to sister chromatids enriched with old $\mathrm{H} 3$ through unknown epigenetic marks at

\section{Concluding remarks and future perspectives}

Because stem cells can also divide symmetrically depending on physiological conditions or stem cell types (Morrison and Kimble 2006; Losick et al. 2011), it will be interesting to investigate whether this asymmetric histone distribution is a unique feature for stem cells or for asymmetric cell divisions. Studies using Drosophila follicle stem cells demonstrate that cells could gain epigenetic stability during differentiation the centromeric region and, possibly, the asymmetric kinetochore structure. Two pairs of sister chromatids from homologous autosomes are shown here. c Co-segregation of sister chromatids from homologous autosomes greatly facilitates asymmetric H3 segregation in anaphase GSCs

(Skora and Spradling 2010), suggesting that not all stem cells maintain a more stable chromatin structure than differentiated cells. Furthermore, a recent study reported asymmetric epigenetic regulation in establishing a bilateral asymmetry in Caenorhabditis elegans neurons (Nakano et al. 2011), suggesting that asymmetrically dividing differentiated cells may also require different epigenetic information. The assays we developed can be applied to other biological systems to understand how epigenetic information is maintained or reconstructed 
during cellular differentiation. We expect to see more exciting advancement on understanding epigenetic inheritance in endogenous stem cell systems in the near future.

Acknowledgments We apologize to people whose work cannot be discussed in this review due to space limitation. We thank Dr. Yukiko Yamashita and Chen lab members for their critical comments on this review. The work in the Chen lab has been supported by R21 HD065089 and R01HD065816 from NICHD/NIH, the Lucile Packard Foundation, and the Johns Hopkins University start-up funding.

\section{References}

Ahmad K, Henikoff S (2002a) Histone H3 variants specify modes of chromatin assembly. Proc Natl Acad Sci U S A 99(Suppl 4):16477-16484

Ahmad K, Henikoff S (2002b) The histone variant H3.3 marks active chromatin by replication-independent nucleosome assembly. Mol Cell 9:1191-1200

Ai X, Parthun MR (2004) The nuclear Hat1p/Hat2p complex: a molecular link between type B histone acetyltransferases and chromatin assembly. Mol Cell 14:195-205

Annunziato AT, Schindler RK, Riggs MG, Seale RL (1982) Association of newly synthesized histones with replicating and nonreplicating regions of chromatin. J Biol Chem 257:8507-8515

Armakolas A, Klar AJ (2006) Cell type regulates selective segregation of mouse chromosome 7 DNA strands in mitosis. Science 311:1146-1149

Armakolas A, Klar AJ (2007) Left-right dynein motor implicated in selective chromatid segregation in mouse cells. Science 315:100-101

Bannister AJ, Kouzarides T (2011) Regulation of chromatin by histone modifications. Cell Res 21:381-395

Bayne EH, White SA, Kagansky A, Bijos DA, Sanchez-Pulido L, Hoe KL, Kim DU, Park HO, Ponting CP, Rappsilber J, Allshire RC (2010) Stc1: a critical link between RNAi and chromatin modification required for heterochromatin integrity. Cell 140:666-677

Berger SL (2007) The complex language of chromatin regulation during transcription. Nature 447:407-412

Bergmann JH, Rodriguez MG, Martins NM, Kimura H, Kelly DA, Masumoto H, Larionov V, Jansen LE, Earnshaw WC (2011) Epigenetic engineering shows $\mathrm{H} 3 \mathrm{~K} 4 \mathrm{me} 2$ is required for HJURP targeting and CENP-A assembly on a synthetic human kinetochore. EMBO J 30:328-340

Bernstein E, Allis CD (2005) RNA meets chromatin. Genes Dev 19:1635-1655

Betschinger J, Knoblich JA (2004) Dare to be different: asymmetric cell division in Drosophila, C. elegans and vertebrates. Curr Biol 14:R674-685

Blower MD, Sullivan BA, Karpen GH (2002) Conserved organization of centromeric chromatin in flies and humans. Dev Cell 2:319-330
Bonasio R, Tu S, Reinberg D (2010) Molecular signals of epigenetic states. Science 330:612-616

Borsani G, Tonlorenzi R, Simmler MC, Dandolo L, Arnaud D, Capra V, Grompe M, Pizzuti A, Muzny D, Lawrence C, Willard HF, Avner P, Ballabio A (1991) Characterization of a murine gene expressed from the inactive $\mathrm{X}$ chromosome. Nature 351:325-329

Cairns J (1975) Mutation selection and the natural history of cancer. Nature 255:197-200

Chen CC, Carson JJ, Feser J, Tamburini B, Zabaronick S, Linger J, Tyler JK (2008) Acetylated lysine 56 on histone $\mathrm{H} 3$ drives chromatin assembly after repair and signals for the completion of repair. Cell 134:231-243

Cheng J, Turkel N, Hemati N, Fuller MT, Hunt AJ, Yamashita YM (2008) Centrosome misorientation reduces stem cell division during ageing. Nature 456:599-604

Chepelev I, Chen X (2013) Alternative splicing switching in stem cell lineages. Front Biol 8:50-59

Clevers H (2005) Stem cells, asymmetric division and cancer. Nat Genet 37:1027-1028

Conboy MJ, Karasov AO, Rando TA (2007) High incidence of non-random template strand segregation and asymmetric fate determination in dividing stem cells and their progeny. PLoS Biol 5:e102

Corpet A, Almouzni G (2009) Making copies of chromatin: the challenge of nucleosomal organization and epigenetic information. Trends Cell Biol 19:29-41

De Koning L, Corpet A, Haber JE, Almouzni G (2007) Histone chaperones: an escort network regulating histone traffic. Nat Struct Mol Biol 14:997-1007

Deal RB, Henikoff JG, Henikoff S (2010) Genome-wide kinetics of nucleosome turnover determined by metabolic labeling of histones. Science 328:1161-1164

Dion MF, Kaplan T, Kim M, Buratowski S, Friedman N, Rando OJ (2007) Dynamics of replication-independent histone turnover in budding yeast. Science 315:1405-1408

Drane P, Ouararhni K, Depaux A, Shuaib M, Hamiche A (2010) The death-associated protein DAXX is a novel histone chaperone involved in the replication-independent deposition of H3.3. Genes Dev 24:1253-1265

Eun SH, Gan Q, Chen X (2010) Epigenetic regulation of germ cell differentiation. Curr Opin Cell Biol 22:737-743

Falconer E, Chavez EA, Henderson A, Poon SS, McKinney S, Brown L, Huntsman DG, Lansdorp PM (2010) Identification of sister chromatids by DNA template strand sequences. Nature 463:93-97

Fei JF, Huttner WB (2009) Nonselective sister chromatid segregation in mouse embryonic neocortical precursor cells. Cereb Cortex 19(Suppl 1):i49-54

Feinberg AP, Ohlsson R, Henikoff S (2006) The epigenetic progenitor origin of human cancer. Nat Rev Genet 7:2133

Ferguson-Smith AC (2011) Genomic imprinting: the emergence of an epigenetic paradigm. Nat Rev Genet 12:565-575

Fischle W, Tseng BS, Dormann HL, Ueberheide BM, Garcia BA, Shabanowitz J, Hunt DF, Funabiki H, Allis CD (2005) Regulation of HP1-chromatin binding by histone $\mathrm{H} 3$ methylation and phosphorylation. Nature 438:1116-1122

Fischle W, Wang Y, Allis CD (2003) Binary switches and modification cassettes in histone biology and beyond. Nature 425:475-479 
Francis NJ (2009a) Does maintenance of polycomb group proteins through DNA replication contribute to epigenetic inheritance? Epigenetics 4:370-373

Francis NJ (2009b) Mechanisms of epigenetic inheritance: copying of polycomb repressed chromatin. Cell Cycle 8:3513-3518

Francis NJ, Follmer NE, Simon MD, Aghia G, Butler JD (2009) Polycomb proteins remain bound to chromatin and DNA during DNA replication in vitro. Cell 137:110-122

Fuller MT, Spradling AC (2007) Male and female Drosophila germline stem cells: two versions of immortality. Science 316:402-404

Gasser R, Koller T, Sogo JM (1996) The stability of nucleosomes at the replication fork. J Mol Biol 258:224-239

Goldberg AD, Banaszynski LA, Noh KM, Lewis PW, Elsaesser SJ, Stadler S, Dewell S, Law M, Guo X, Li X, Wen D, Chapgier A, DeKelver RC, Miller JC, Lee YL, Boydston EA, Holmes MC, Gregory PD, Greally JM, Rafii S, Yang C, Scambler PJ, Garrick D, Gibbons RJ, Higgs DR, Cristea IM, Urnov FD, Zheng D, Allis CD (2010) Distinct factors control histone variant H3.3 localization at specific genomic regions. Cell 140:678-691

Guilbaud G, Rappailles A, Baker A, Chen CL, Arneodo A, Goldar A, D'Aubenton-Carafa Y, Thermes C, Audit B, Hyrien O (2011) Evidence for sequential and increasing activation of replication origins along replication timing gradients in the human genome. PLoS Comput Biol 7:e1002322

Hansen KH, Helin K (2009) Epigenetic inheritance through self-recruitment of the polycomb repressive complex 2 . Epigenetics 4:133-138

Henikoff S, Furuyama T, Ahmad K (2004a) Histone variants, nucleosome assembly and epigenetic inheritance. Trends Genet 20:320-326

Henikoff S, McKittrick E, Ahmad K (2004b) Epigenetics, histone $\mathrm{H} 3$ variants, and the inheritance of chromatin states. Cold Spring Harb Symp Quant Biol 69:235-243

Hung MS, Karthikeyan N, Huang B, Koo HC, Kiger J, Shen CJ (1999) Drosophila proteins related to vertebrate DNA (5-cytosine) methyltransferases. Proc Natl Acad Sci U S A 96:11940-11945

Inaba M, Yamashita YM (2012) Asymmetric stem cell division: precision for robustness. Cell Stem Cell 11:461-469

Inaba M, Yuan H, Salzmann V, Fuller MT, Yamashita YM (2010) E-cadherin is required for centrosome and spindle orientation in Drosophila male germline stem cells. PLoS One 5:e12473

Irvine DV, Zaratiegui M, Tolia NH, Goto DB, Chitwood DH, Vaughn MW, Joshua-Tor L, Martienssen RA (2006) Argonaute slicing is required for heterochromatic silencing and spreading. Science 313:1134-1137

Jackson V, Chalkley R (1981a) A new method for the isolation of replicative chromatin: selective deposition of histone on both new and old DNA. Cell 23:121-134

Jackson V, Chalkley R (1981b) A reevaluation of new histone deposition on replicating chromatin. J Biol Chem 256:5095-5103

Jackson V, Shires A, Tanphaichitr N, Chalkley R (1976) Modifications to histones immediately after synthesis. J Mol Biol 104:471-483

Jacobs JJ, van Lohuizen M (2002) Polycomb repression: from cellular memory to cellular proliferation and cancer. Biochim Biophys Acta 1602:151-161
Jaenisch R, Young R (2008) Stem cells, the molecular circuitry of pluripotency and nuclear reprogramming. Cell 132:567-582

Jenuwein T, Allis CD (2001) Translating the histone code. Science 293:1074-1080

Kamakaka RT, Biggins S (2005) Histone variants: deviants? Genes Dev 19:295-310

Kapoor TM, Lampson MA, Hergert P, Cameron L, Cimini D, Salmon ED, McEwen BF, Khodjakov A (2006) Chromosomes can congress to the metaphase plate before biorientation. Science 311:388-391

Karpowicz P, Morshead C, Kam A, Jervis E, Ramunas J, Cheng V, van der Kooy D (2005) Support for the immortal strand hypothesis: neural stem cells partition DNA asymmetrically in vitro. J Cell Biol 170:721-732

Karpowicz P, Pellikka M, Chea E, Godt D, Tepass U, van der Kooy D (2009) The germline stem cells of Drosophila melanogaster partition DNA non-randomly. Eur J Cell Biol 88:397-408

Kiel MJ, He S, Ashkenazi R, Gentry SN, Teta M, Kushner JA, Jackson TL, Morrison SJ (2007) Haematopoietic stem cells do not asymmetrically segregate chromosomes or retain BrdU. Nature 449:238-242

Kiger AA, Jones DL, Schulz C, Rogers MB, Fuller MT (2001) Stem cell self-renewal specified by JAK-STAT activation in response to a support cell cue. Science 294:2542-2545

Klar AJ (1994) A model for specification of the left-right axis in vertebrates. Trends Genet 10:392-396

Klar AJ (2007) Lessons learned from studies of fission yeast mating-type switching and silencing. Annu Rev Genet 41:213-236

Knoblich JA (2008) Mechanisms of asymmetric stem cell division. Cell 132:583-597

Konev AY, Tribus M, Park SY, Podhraski V, Lim CY, Emelyanov AV, Vershilova E, Pirrotta V, Kadonaga JT, Lusser A, Fyodorov DV (2007) CHD1 motor protein is required for deposition of histone variant H3.3 into chromatin in vivo. Science 317:1087-1090

Kouskouti A, Talianidis I (2005) Histone modifications defining active genes persist after transcriptional and mitotic inactivation. EMBO J 24:347-357

Lansdorp PM (2007) Immortal strands? Give me a break. Cell 129:1244-1247

Leatherman JL, Dinardo S (2008) Zfh-1 controls somatic stem cell self-renewal in the Drosophila testis and nonautonomously influences germline stem cell self-renewal. Cell Stem Cell 3:44-54

Leatherman JL, Dinardo S (2010) Germline self-renewal requires cyst stem cells and stat regulates niche adhesion in Drosophila testes. Nat Cell Biol 12:806-811

Lengsfeld BM, Berry KN, Ghosh S, Takahashi M, Francis NJ (2012) A polycomb complex remains bound through DNA replication in the absence of other eukaryotic proteins. Sci Rep 2:661

Lew DJ, Burke DJ, Dutta A (2008) The immortal strand hypothesis: how could it work? Cell 133:21-23

Li Q, Zhou H, Wurtele H, Davies B, Horazdovsky B, Verreault A, Zhang Z (2008) Acetylation of histone H3 lysine 56 regulates replication-coupled nucleosome assembly. Cell 134:244-255

Lim C, Tarayrah L, Chen X (2012) Transcriptional regulation during Drosophila spermatogenesis. Spermatogenesis 2:158-166 
Lo SM, Follmer NE, Lengsfeld BM, Madamba EV, Seong S, Grau DJ, Francis NJ (2012) A bridging model for persistence of a polycomb group protein complex through DNA replication in vitro. Mol Cell 46:784-796

Losick VP, Morris LX, Fox DT, Spradling A (2011) Drosophila stem cell niches: a decade of discovery suggests a unified view of stem cell regulation. Dev Cell 21:159-171

Lyko F, Ramsahoye BH, Jaenisch R (2000a) DNA methylation in Drosophila melanogaster. Nature 408:538-540

Lyko F, Whittaker AJ, Orr-Weaver TL, Jaenisch R (2000b) The putative Drosophila methyltransferase gene dDnmt2 is contained in a transposon-like element and is expressed specifically in ovaries. Mech Dev 95:215-217

Malik HS, Henikoff S (2009) Major evolutionary transitions in centromere complexity. Cell 138:1067-1082

Martin C, Zhang Y (2007) Mechanisms of epigenetic inheritance. Curr Opin Cell Biol 19:266-272

Masumoto H, Hawke D, Kobayashi R, Verreault A (2005) A role for cell-cycle-regulated histone H3 lysine 56 acetylation in the DNA damage response. Nature 436:294-298

McNairn AJ, Gilbert DM (2003) Epigenomic replication: linking epigenetics to DNA replication. BioEssays 25:647-656

Mellone BG, Grive KJ, Shteyn V, Bowers SR, Oderberg I, Karpen GH (2011) Assembly of Drosophila centromeric chromatin proteins during mitosis. PLoS Genet 7: e1002068

Merok JR, Lansita JA, Tunstead JR, Sherley JL (2002) Cosegregation of chromosomes containing immortal DNA strands in cells that cycle with asymmetric stem cell kinetics. Cancer Res 62:6791-6795

Min J, Zhang Y, Xu RM (2003) Structural basis for specific binding of polycomb chromodomain to histone $\mathrm{H} 3$ methylated at Lys 27. Genes Dev 17:1823-1828

Mito Y, Henikoff JG, Henikoff S (2007) Histone replacement marks the boundaries of cis-regulatory domains. Science 315:1408-1411

Moggs JG, Grandi P, Quivy JP, Jonsson ZO, Hubscher U, Becker PB, Almouzni G (2000) A CAF-1-PCNA-mediated chromatin assembly pathway triggered by sensing DNA damage. Mol Cell Biol 20:1206-1218

Morrison SJ, Kimble J (2006) Asymmetric and symmetric stemcell divisions in development and cancer. Nature 441:1068-1074

Morrison SJ, Spradling AC (2008) Stem cells and niches: mechanisms that promote stem cell maintenance throughout life. Cell 132:598-611

Mostoslavsky R, Alt FW, Rajewsky K (2004) The lingering enigma of the allelic exclusion mechanism. Cell 118:539-544

Motamedi MR, Verdel A, Colmenares SU, Gerber SA, Gygi SP, Moazed D (2004) Two RNAi complexes, RITS and RDRC, physically interact and localize to noncoding centromeric RNAs. Cell 119:789-802

Nakano S, Stillman B, Horvitz HR (2011) Replication-coupled chromatin assembly generates a neuronal bilateral asymmetry in C. elegans. Cell 147:1525-1536

Petruk S, Sedkov Y, Johnston DM, Hodgson JW, Black KL, Kovermann SK, Beck S, Canaani E, Brock HW, Mazo A (2012) TrxG and PcG proteins but not methylated histones remain associated with DNA through replication. Cell 150:922-933
Pine SR, Ryan BM, Varticovski L, Robles AI, Harris CC (2010) Microenvironmental modulation of asymmetric cell division in human lung cancer cells. Proc Natl Acad Sci U S A 107:2195-2200

Potten CS, Owen G, Booth D (2002) Intestinal stem cells protect their genome by selective segregation of template DNA strands. J Cell Sci 115:2381-2388

Quyn AJ, Appleton PL, Carey FA, Steele RJ, Barker N, Clevers H, Ridgway RA, Sansom OJ, Nathke IS (2010) Spindle orientation bias in gut epithelial stem cell compartments is lost in precancerous tissue. Cell Stem Cell 6:175-181

Rando TA (2006) Stem cells, ageing and the quest for immortality. Nature 441:1080-1086

Rando TA (2007) The immortal strand hypothesis: segregation and reconstruction. Cell 129:1239-1243

Ray-Gallet D, Quivy JP, Scamps C, Martini EM, Lipinski M, Almouzni G (2002) HIRA is critical for a nucleosome assembly pathway independent of DNA synthesis. Mol Cell 9:1091-1100

Rebollo E, Sampaio P, Januschke J, Llamazares S, Varmark H, Gonzalez C (2007) Functionally unequal centrosomes drive spindle orientation in asymmetrically dividing Drosophila neural stem cells. Dev Cell 12:467-474

Recht J, Tsubota T, Tanny JC, Diaz RL, Berger JM, Zhang X, Garcia BA, Shabanowitz J, Burlingame AL, Hunt DF, Kaufman PD, Allis CD (2006) Histone chaperone Asfl is required for histone $\mathrm{H} 3$ lysine 56 acetylation, a modification associated with $\mathrm{S}$ phase in mitosis and meiosis. Proc Natl Acad Sci U S A 103:6988-6993

Richards EJ, Elgin SC (2002) Epigenetic codes for heterochromatin formation and silencing: rounding up the usual suspects. Cell 108:489-500

Ringrose L, Paro R (2004) Epigenetic regulation of cellular memory by the polycomb and trithorax group proteins. Annu Rev Genet 38:413-443

Rinn JL, Chang HY (2012) Genome regulation by long noncoding RNAs. Annu Rev Biochem 81:145-166

Rocheteau P, Gayraud-Morel B, Siegl-Cachedenier I, Blasco MA, Tajbakhsh S (2012) A subpopulation of adult skeletal muscle stem cells retains all template DNA strands after cell division. Cell 148:112-125

Rossi DJ, Jamieson CH, Weissman IL (2008) Stems cells and the pathways to aging and cancer. Cell 132:681-696

Roth TM, Chiang CY, Inaba M, Yuan H, Salzmann V, Roth CE, Yamashita YM (2012) Centrosome misorientation mediates slowing of the cell cycle under limited nutrient conditions in Drosophila male germline stem cells. Mol Biol Cell 23:1524-1532

Ruiz-Carrillo A, Wangh LJ, Allfrey VG (1975) Processing of newly synthesized histone molecules. Science 190:117-128

Russev G, Hancock R (1981) Formation of hybrid nucleosomes containing new and old histones. Nucleic Acids Res 9:4129-4137

Saha A, Wittmeyer J, Cairns BR (2006) Chromatin remodelling: the industrial revolution of DNA around histones. Nat Rev Mol Cell Biol 7:437-447

Schreiber SL, Bernstein BE (2002) Signaling network model of chromatin. Cell 111:771-778

Schuh M, Lehner CF, Heidmann S (2007) Incorporation of Drosophila CID/CENP-A and CENP-C into centromeres during early embryonic anaphase. Curr Biol 17:237-243 
Schwartz BE, Ahmad K (2005) Transcriptional activation triggers deposition and removal of the histone variant H3.3. Genes Dev 19:804-814

Seale RL (1975) Assembly of DNA and protein during replication in HeLa cells. Nature 255:247-249

Sheng XR, Matunis E (2011) Live imaging of the Drosophila spermatogonial stem cell niche reveals novel mechanisms regulating germline stem cell output. Development 138:3367-3376

Shibahara K, Stillman B (1999) Replication-dependent marking of DNA by PCNA facilitates CAF-1-coupled inheritance of chromatin. Cell 96:575-585

Shinin V, Gayraud-Morel B, Gomes D, Tajbakhsh S (2006) Asymmetric division and cosegregation of template DNA strands in adult muscle satellite cells. Nat Cell Biol 8:677687

Skora AD, Spradling AC (2010) Epigenetic stability increases extensively during Drosophila follicle stem cell differentiation. Proc Natl Acad Sci U S A 107:7389-7394

Smith DJ, Whitehouse I (2012) Intrinsic coupling of laggingstrand synthesis to chromatin assembly. Nature 483:434 438

Smith GH (2005) Label-retaining epithelial cells in mouse mammary gland divide asymmetrically and retain their template DNA strands. Development 132:681-687

Sotiropoulou PA, Candi A, Blanpain C (2008) The majority of multipotent epidermal stem cells do not protect their genome by asymmetrical chromosome segregation. Stem Cells 26:2964-2973

Sullivan BA, Karpen GH (2004) Centromeric chromatin exhibits a histone modification pattern that is distinct from both euchromatin and heterochromatin. Nat Struct Mol Biol 11:10761083

Szenker E, Ray-Gallet D, Almouzni G (2011) The double face of the histone variant H3.3. Cell Res 21:421-434

Tajbakhsh S, Gonzalez C (2009) Biased segregation of DNA and centrosomes: moving together or drifting apart? Nat Rev Mol Cell Biol 10:804-810

Thorpe PH, Bruno J, Rothstein R (2009) Kinetochore asymmetry defines a single yeast lineage. Proc Natl Acad Sci U S A 106:6673-6678

Toledano H, D'Alterio C, Czech B, Levine E, Jones DL (2012) The let-7-Imp axis regulates ageing of the Drosophila testis stem-cell niche. Nature 485:605-610

Tran V, Lim C, Xie J, Chen X (2012) Asymmetric division of Drosophila male germline stem cell shows asymmetric histone distribution. Science 338:679-682

Tulina N, Matunis E (2001) Control of stem cell self-renewal in Drosophila spermatogenesis by JAK-STAT signaling. Science 294:2546-2549

Turner BM (2002) Cellular memory and the histone code. Cell 111:285-291

Vagnarelli P, Ribeiro SA, Earnshaw WC (2008) Centromeres: old tales and new tools. FEBS Lett 582:1950-1959

Valls E, Sanchez-Molina S, Martinez-Balbas MA (2005) Role of histone modifications in marking and activating genes through mitosis. J Biol Chem 280:4259242600

Verdaasdonk JS, Bloom K (2011) Centromeres: unique chromatin structures that drive chromosome segregation. Nat Rev Mol Cell Biol 12:320-332
Verreault A, Kaufman PD, Kobayashi R, Stillman B (1996) Nucleosome assembly by a complex of CAF-1 and acetylated histones $\mathrm{H} 3 / \mathrm{H} 4$. Cell 87:95-104

Verzijlbergen KF, Menendez-Benito V, van Welsem T, van Deventer SJ, Lindstrom DL, Ovaa H, Neefjes J, Gottschling DE, van Leeuwen F (2010) Recombinationinduced tag exchange to track old and new proteins. Proc Natl Acad Sci U S A 107:64-68

Waghmare SK, Bansal R, Lee J, Zhang YV, McDermitt DJ, Tumbar T (2008) Quantitative proliferation dynamics and random chromosome segregation of hair follicle stem cells. EMBO J 27:1309-1320

Wang X, Tsai JW, Imai JH, Lian WN, Vallee RB, Shi SH (2009) Asymmetric centrosome inheritance maintains neural progenitors in the neocortex. Nature 461:947-955

White MA, Eykelenboom JK, Lopez-Vernaza MA, Wilson E, Leach DR (2008) Non-random segregation of sister chromosomes in Escherichia coli. Nature 455:1248-1250

Xu M, Long C, Chen X, Huang C, Chen S, Zhu B (2010) Partitioning of histone $\mathrm{H} 3-\mathrm{H} 4$ tetramers during DNA replication-dependent chromatin assembly. Science 328:94-98

Yadlapalli S, Cheng J, Yamashita YM (2011a) Drosophila male germline stem cells do not asymmetrically segregate chromosome strands. J Cell Sci 124:933-939

Yadlapalli S, Cheng J, Yamashita YM (2011b) Reply to: Overlooked areas need attention for sound evaluation of DNA strand inheritance patterns in Drosophila male germline stem cells. J Cell Sci 124:4138-4139

Yadlapalli S, Yamashita YM (2013) Chromosome-specific nonrandom sister chromatid segregation during stem cell division. Nature. doi:10.1038/nature12106

Yamashita YM (2013) Non-random sister chromatid segregation of sex chromosomes in Drosophila male germline stem cells. Chromosome Research, in this issue

Yamashita YM, Fuller MT (2005) Asymmetric stem cell division and function of the niche in the Drosophila male germ line. Int J Hematol 82:377-380

Yamashita YM, Fuller MT, Jones DL (2005) Signaling in stem cell niches: lessons from the Drosophila germline. J Cell Sci 118:665-672

Yamashita YM, Jones DL, Fuller MT (2003) Orientation of asymmetric stem cell division by the APC tumor suppressor and centrosome. Science 301:1547-1550

Yamashita YM, Mahowald AP, Perlin JR, Fuller MT (2007) Asymmetric inheritance of mother versus daughter centrosome in stem cell division. Science 315:518-521

Yuan H, Chiang CY, Cheng J, Salzmann V, Yamashita YM (2012a) Regulation of cyclin A localization downstream of Par-1 function is critical for the centrosome orientation checkpoint in Drosophila male germline stem cells. Dev Biol 361:57-67

Yuan W, Wu T, Fu H, Dai C, Wu H, Liu N, Li X, Xu M, Zhang Z, Niu T, Han Z, Chai J, Zhou XJ, Gao S, Zhu B (2012b) Dense chromatin activates polycomb repressive complex 2 to regulate H3 lysine 27 methylation. Science 337:971-975

Zhao J, Sun BK, Erwin JA, Song JJ, Lee JT (2008) Polycomb proteins targeted by a short repeat RNA to the mouse $\mathrm{X}$ chromosome. Science 322:750-756

Zhu B, Reinberg D (2011) Epigenetic inheritance: uncontested? Cell Res 21:435-441 